$11-1-2011$

\title{
Robert Milton Zollinger, M.D., teacher, surgeon, soldier, and farmer.
}

Fiona M. Chory, B.S.

Thomas Jefferson University

Charles J. Yeo, MD

Thomas Jefferson University

Pinckney J. Maxwell, IV, MD

Thomas Jefferson University

Follow this and additional works at: https://jdc.jefferson.edu/gibbonsocietyprofiles

Part of the History of Science, Technology, and Medicine Commons, and the Surgery Commons Let us know how access to this document benefits you

\section{Recommended Citation}

Chory, B.S., Fiona M.; Yeo, MD, Charles J.; and Maxwell, IV, MD, Pinckney J., "Robert Milton Zollinger, M.D., teacher, surgeon, soldier, and farmer." (2011). Department of Surgery Gibbon Society Historical Profiles. Paper 34.

https://jdc.jefferson.edu/gibbonsocietyprofiles/34

This Article is brought to you for free and open access by the Jefferson Digital Commons. The Jefferson Digital Commons is a service of Thomas Jefferson University's Center for Teaching and Learning (CTL). The Commons is a showcase for Jefferson books and journals, peer-reviewed scholarly publications, unique historical collections from the University archives, and teaching tools. The Jefferson Digital Commons allows researchers and interested readers anywhere in the world to learn about and keep up to date with Jefferson scholarship. This article has been accepted for inclusion in Department of Surgery Gibbon Society Historical Profiles by an authorized administrator of the Jefferson Digital Commons. For more information, please contact: JeffersonDigitalCommons@jefferson.edu. 


\title{
Robert Milton Zollinger, M.D., Teacher, Surgeon, Soldier, and Farmer
}

FIONA M. CHORY, B.S., CHARLES J. YEO, M.D., PINCKNEY J. MAXWELL IV, M.D.

\author{
From the Department of Surgery, Jefferson Medical College of Thomas Jefferson University,
} Philadelphia, Pennsylvania

$\mathrm{F}$ ROM HUMBLE ROOTS, Dr. Robert Milton Zollinger worked his way to a position in history among the giants of American surgery. He was born on September 4, 1903, in the central Ohio town of Millersport, the son of Elmira and William Zollinger. Neither of his parents had a high school education, but they supported education and always expressed a confidence that young Robert would be successful at anything he attempted. ${ }^{1}$ He had aspirations of attending West Point, a dream that was never fulfilled when he decided to be a surgeon. On being informed of his son's intentions, Zollinger's father bestowed on him advice that he ostensibly adhered to throughout his career: "If you are going to be a doctor, be a good one."

He entered Ohio State University (OSU) in nearby Columbus as an undergraduate in 1921, the first graduate from his high school to attend college and only the second from his family. ${ }^{2}$ At the time, OSU offered a 6-year combined bachelor and medical degree program and "was the only college that he knew about." He received his B.A. degree in 1925 followed by his M.D. degree 2 years later. ${ }^{2}$ Despite earning a " $C$ " in surgery, Zollinger never considered any other specialty. He even boasted that he would return (to OSU) as the head of the surgery department someday. ${ }^{1}$

Zollinger interviewed with Dr. Harvey Cushing for an internship at the Peter Bent Brigham Hospital (PBBH), an appointment he received and was to begin January 1, 1928. In his acceptance letter, Dr. Cushing suggested that Zollinger take a 6-month volunteer extern position with Dr. Elliot C. Cutler before the start of his internship. ${ }^{1}$ Cutler was Director (Chairman) of Surgery at Western Reserve Medical School, at Lakeside Hospital in Cleveland, and he would become a prominent influence in Zollinger's training and beyond. Zollinger spent most of his time there in the new Pathology Institute building, studying Cutler's brain tumor specimens, an

Address correspondence and reprint requests to Pinckney J. Maxwell IV, M.D., Assistant Professor of Surgery, Division of Colon and Rectal Surgery, Department of Surgery, Jefferson Medical College of Thomas Jefferson University, 1100 Walnut Street, Suite 500, Philadelphia, PA 19107. E-mail: Pinckney. Maxwell@jefferson.edu. effort from which he gained his first publication in the April 1929 issue of the Ohio State Medical Journal: "A Histologic Study of Tumors of the Central Nervous System." He was also instructed to attend the medical gastrointestinal follow-up clinic, an experience that would create an interest in gastric hypersecretion for the future. ${ }^{1}$

After his work with Cutler at Western Reserve, Dr. Zollinger went to Boston and completed his surgical internship at the $\mathrm{PBBH}$. He subsequently returned to Cleveland to begin his residency with Dr. Cutler at Lakeside Hospital. In 1930, he received the Crile Fellowship in Surgery, a prestigious honor named after Dr. George Washington Crile, the sixth chairman of the Department of Surgery at Western Reserve. When Cutler was invited back to Boston in 1932 as Cushing's successor as the Mosley Professor of Surgery and Surgeonin-Chief at the PBBH, he brought Dr. Zollinger with him (Fig. 1). Dr. Zollinger completed 2 years as chief resident and by 1939 was an Assistant Professor of Surgery at Harvard Medical School and an Associate in Surgery. During this time together, he and Dr. Cutler prepared the first edition of the now famous Atlas of Surgical Operations, which was published in 1939 by Macmillan Publishing Company. The first of nine editions, it contained 84 plates in 181 pages and sold for $\$ 15 .{ }^{3}$

With the United States involvement in World War II, Dr. Zollinger, Dr. Cutler, and the Harvard staff reconstituted the "Harvard Unit," the Fifth General Hospital of the Army Medical Corps. Dr. Zollinger began as a Major and Assistant Chief of Surgery and rose to the rank of Colonel during $3 \frac{1}{2} 2$ years of service. The academic endeavors and "quality improvement" interests of Drs. Cutler and Zollinger were not idled by the war. Dr. Zollinger and Dr. Cutler created the Manual of Therapy for the European Theater of Operations, United States Army, a succinct, pocket-sized text illustrating the principles of emergency care and the treatment of specific traumatic injuries. ${ }^{3}$ Another great contribution to U.S. military surgery, for which he earned the Legion of Merit, was the development of mobile surgical units that were equipped to perform 100 major operations. 
After returning very briefly to Harvard after the war, Dr. Zollinger was offered a position as Professor of Surgery at his alma mater, OSU. It was understood that he would succeed Dr. Verne Dodd, the professor who awarded him a "C" in surgery as a medical student, as the fourth Chairman of the Department of Surgery. Dr. Dodd had remembered Zollinger's vow to return as head of the surgery department, and he personally wrote to him in France in 1945 to offer him the position. In 1947, Dr. Zollinger assumed the Chair, beginning his nearly 30-year tenure during which he would recruit personnel, develop the existing surgical specialties, aid the establishment of new surgical divisions, and expand the medical facilities.

The surgery service at OSU post-World War II was small and was divided into clinical surgery and research surgery divisions. ${ }^{4}$ Dr. Zollinger reorganized the general surgical service to mimic the strategies used by Drs. Cushing and Cutler, his respected professors and colleagues. The residency was established as a 5-year program with a straight surgical internship and incorporated a research program. ${ }^{4}$ Dr. Zollinger was a strict taskmaster with a passion for perfection and excellence who was determined to uphold the Halsted-Cutler Spartan tradition.

One of the first and most notable faculty members recruited by Dr. Zollinger was Dr. Edwin Ellison. By 1954, Drs. Zollinger and Ellison had reported on at least 100 patients with ulcer disease evaluated 5 years after surgical intervention. Both men had encountered patients with refractory ulcer disease, gastric hypersecretion, and excessive acidity despite several procedures. On April 29, 1955, the two surgeons presented their description of the Zollinger-Ellison syndrome before the American Surgical Association in Philadelphia, PA. The article, "Primary Peptic Ulcerations of the Jejunum Associated with Islet Cell Tumors of the Pancreas," was published in the Annals of Surgery in October of the same year. Interestingly, they presented theoretical reasons and electrophoretic analysis of the serum of the one living patient that implicated glucagon as the putative mediator of the syndrome.

Dr. Zollinger's article with Dr. Ellison secured him a medical eponym, but it was only one of the many publications bearing Dr. Zollinger's name. A prolific writer and dedicated clinician, Dr. Zollinger published approximately 360 articles. He held many editorial appointments including Editor-in-Chief of The American Journal of Surgery and of the British Journal of Clinical Practice. His Atlas is now the 9th edition and has been published in eight languages. He also coauthored later editions of Cole and Elman's Textbook of Surgery with Dr. Warren H. Cole.

Dr. Zollinger retired in 1974 but continued his quest for excellence in surgery as Professor and Chairman
Emeritus of the Department of Surgery. He continued to lecture at OSU and around the world. He was a wellknown master surgeon and educator throughout his career and was the recipient of numerous awards, fellowships, degrees, and appointments. Notably, Dr. Zollinger is one of the few surgeons to be honored as the president of the American College of Surgeons (Fig. 2), the president of the American Surgical Association, and Chairman of the American Board of Surgery. He excelled in his interests outside of the surgical realm as well, growing award-winning gourds and roses and serving as the President of the American Rose Society. Dr. Zollinger's other recognitions include the presidency of the Society of Medical Consultants of World War II, a founding member of the Society of University Surgeons, an honorary degree from the University of Lyon, France (1965), honorary fellowships in the Royal College of Surgeons of England (1965) and the Royal College of Surgeons of

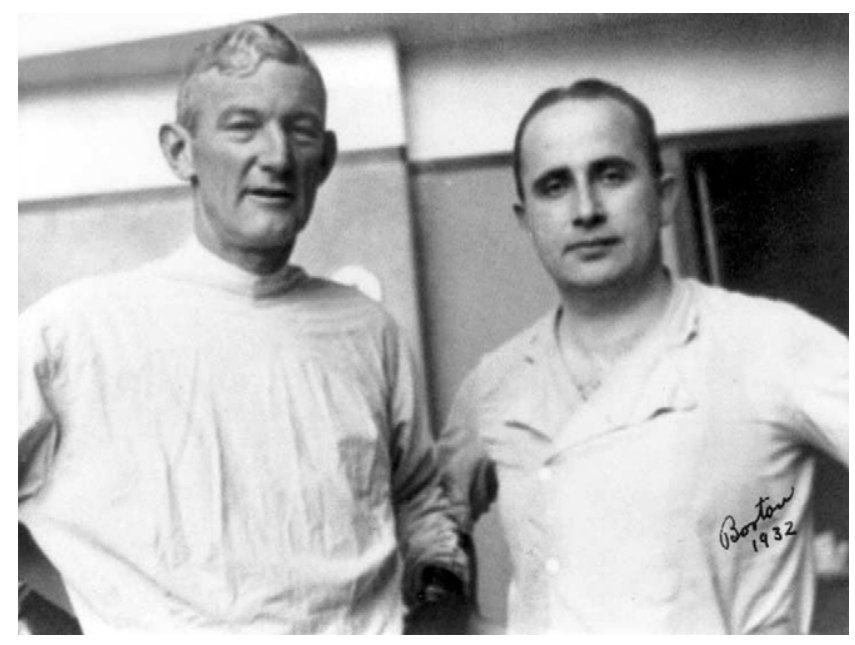

FIG. 1. Zollinger, right, and Cutler in a Boston surgery in 1932. Originally published in McGarey M, Ellison EC. He holds the triple crown of surgery. Am J Surg 2003;186:238-41. From the collections of the Medical Heritage Center, Prior Health Sciences Library, Ohio State University, Columbus, Ohio.

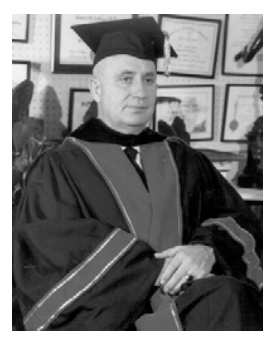

FIG. 2. Zollinger as president of the American College of Surgeons. Originally published in McGarey M, Ellison EC. He holds the triple crown of surgery. Am J Surg 2003;186:238-41. From the collections of the Medical Heritage Center, Prior Health Sciences Library, Ohio State University, Columbus, Ohio. 
Edinburgh (1966), the American Medical Association's Sheen Award (1977), the Gold-Headed Cane Award from the University of California, the 50-year Gold Medal Award of the PBBH, the American Surgical Association Distinguished Achievement Award, and the Joseph M. Sullivan Medal Award of OSU. Dr. Zollinger was offered the presidency of OSU, a position which he declined.

Dr. Zollinger died of pancreatic cancer on June 12, 1992, at the age of 88. The Zollinger Surgical Society at the Ohio State College Medical continues to regularly honor Dr. Zollinger's memory with a lectureship and a scientific meeting.

\section{REFERENCES}

1. Van Brimmer B. Dr. Robert M. Zollinger: his legacy. Am J Surg 2003;186:217-23.

2. Lewis L, Van Brimmer B. A biography of Robert Milton Zollinger, M.D. Am J Surg 2003;186:205-7.

3. Zollinger RM. The Atlas of Surgical Operations: Elliott Carr Cutler and Robert Zollinger. Am J Surg 2003;186:211-6.

4. Zollinger RM, Ellison EC. A history of the Ohio State University Department of Surgery. Am J Surg 2003;186:208-10. 